\title{
Corporate social responsibility of the Port of Gdynia
}

\author{
Hanna Klimek ${ }^{1,}$, and Janusz Dąbrowski ${ }^{1, *}$ \\ ${ }^{1}$ University of Gdańsk, Faculty of Economics, 119/121 Armii Krajowej St., 81-824 Sopot, Poland
}

\begin{abstract}
Corporate social responsibility (CSR) is a tool used by companies to establish positive relations with their surroundings and gain a competitive edge. This also relates to centres providing services, such as seaports. In the past, these served as loading/off-loading and storage stations as well as ship terminals. At present, they have become versatile complexes administering land and infrastructure as well as playing host to numerous enterprises which offer a wide range of services to carriers and freight forwarders. Not only individual businesses but also entire port service hubs can, or even should, be socially responsible nowadays. The topic of this research is the social responsibility of sea ports. This article will discuss the social responsibility of the Port of Gdynia. The objective is to present socially responsible actions taken by Gdynia Port Authority SA and the largest port operators and to assess the progress made on the implementation of CSR there.
\end{abstract}

\section{Introduction}

Seaports and, in particular, their authorities are taking an increasing interest in the implementation of corporate social responsibility. This comes as a consequence of the profile of their operations whereby seaports exert a considerable impact on the environment and generate numerous external effects, while most of port authorities serve public functions. With all this, port operators are also commercial entities and vital links in the supply chain, trying to build a competitive edge and having a large number of stakeholders.

The aim of this paper is to verify the hypothesis that the Port of Gdynia is at present a socially responsible seaport. This paper will attempt in particular to identify the areas of the port's social responsibility and the extent to which action is being taken therein by the port's management body and operators.

The article starts with a general description of Gdynia's seaport, followed by historical background information and a review of the literature on corporate social responsibility at seaports. Next comes a discussion of research methods, while the largest space is dedicated to the currently on-going activities in which Gdynia Port Authority SA and commercial enterprises engage as part of corporate social responsibility (CSR). The paper closes with a discussion of the research results.

The Port of Gdynia is situated on the Baltic Sea's southern coast. Excellently navigable, easily accessible by sea, frost-free and tideless, it is operates regular maritime routes to

\footnotetext{
* Corresponding author: drjanuszdabrowski@gmail.com
} 
Scandinavia, Great Britain, Germany, the Netherlands, Russia, the Mediterranean and Central America, as well as a number of irregular shipping services which allow the carriage of mass cargo from/to South and North America, Asia (India, China), Australia, Africa and EU countries. The port itself is well-connected with its hinterland by road and rail. The Port of Gdynia is one of Poland's four ports whose importance is essential to the national economy. It also forms part of the Baltic-Adriatic transport corridor within TEN-T[1], which makes it a first-rank transport system among the EU's land-to-sea transport chains.

The port's premises are governed by Zarząd Morskiego Portu Gdynia SA [The Port of Gdynia Authority SA] (henceforth: ZMPG-a SA). It is incorporated as a public utility entity, with three shareholders: the State Treasury $(99.4830 \%)$, the commune of Gdynia $(0.0436 \%)$ and registered shareholders $(0.4734 \%)$ [2].

ZMPG-a SA's main area of business is the management of the Port of Gdynia in compliance with port law and the company statute, including in particular real estate and infrastructure governance at port, forecasting, programming and planning of port development; construction, extension, maintenance and modernization of the port's infrastructure; supplying infrastructural services at port, including telecommunications and IT, water-side fire protection of buildings, premises, ships and other seagoing vessels stationed at the port's entry-point as well assurance of access to the port's sewage-draining installations [3]. ZMPG-a SA is not allowed to do business other than stated above.

There are a number of commercial enterprises operating on the port's premises and taking advantage of its facilities. The port has two cargo handling areas:

- western terminal section operated by Bałtycki Terminal Kontenerowy Sp. z o.o., Gdynia Container Terminal S.A., Terminal Promowy Stena Line Polska Sp. z o.o.,

- eastern terminal section operated by Bałtycki Terminal Zbożowy Sp. z.o.o, Morski Terminal Masowy Gdynia Sp. z o.o., OT Port Gdynia Sp. z o.o.; Bałtycka Baza Masowa Sp. z o.o., Koole Tankstorage Gdynia Sp. z o.o., Terminal ONICO GAS Sp. z o.o., Aalborg Portland Polska Sp. z o.o., Speed Sp. z o.o.

The port is also home to businesses offering towing, pilotage, bunkering, overhaul and maintenance services. The businesses offering cargo and transport services are supported by other (power generation, heating, cargo handling) entities. The Port of Gdynia also houses other service providers, e.g. waste disposal ( 3 entities), shipping companies ( 22 entities) and agents (36 entities), freight forwarders (76 entities), property valuers and controllers (14 entities), rail carriers (5 entities), which operate between the port and its hinterland, as well as other authorities, chambers and supervisory bodies regulating the activities at port (over 10 institutions). The port would not exist without the shipping industry represented by Nauta, Crist and Remontowa Vistal Shipyard, other manufacturing companies and the Special Pomeranian Economic Zone. Safety is maintained by the Port's Fire Brigade in cooperation with the State Fire Brigade.

As can be seen, the supply center of port services known as 'Port of Gdynia' consists of numerous entities operating under a common label. Its business interests lie at the intersection of economic, social and environmental concerns. The interactions are numerous and so are the stakeholders.

\section{Corporate social responsibility background and literature review}

The debate on socially responsible commerce and the impact of commercial activities on society dates back to ancient China, Egypt and Sumer [4, 5]. The interest in the negative impact of business activities on the environment intensified during the Industrial Revolution, especially in Great Britain and the USA. At that time, industrial growth was perceived as a source of increasing social problems, as public opinion pressurized business owners to engage in philanthropic initiatives. Reports exists of businesspeople setting aside part of their income for 
orphanages, foundations and charities, with notable examples including D. Dale, a cotton merchant from New Lanark in Scotland, a socialist utopian R. Owen [6] and A. Carnegie, the founder of US Steel Corporation and a forerunner of social responsibility based on the principles of charity and stewardship [7].

From the 1930 s to 1950 s, corporate social responsibility was understood mainly as improving employee welfare, work safety, medical care and pension plans [8]. A breakthrough came in the 1950s with the publication of a book entitled "Social Responsibilities of the Businessman" by H. Bowen, now regarded as "the father of social responsibility of business." His approach conceptualized CSR as business people's obligation to have regard to goals and values embraced by a given society through decision-making, actions and corporate policy [9].

The 1960s/70s saw a dynamic growth of CSR sparked by two great social (ecological and consumer) movements. The question of corporate social responsibility was raised, leading to A. Corroll proposing its first generally accepted definition and the so-called social pyramid of business responsibility. According to Corroll, CSR relates to the responsibility of enterprises for taking economic, legal, ethical and philanthropic action expected by society at a given time [10]. Responsibility was broken down into a number of areas, modelled after A. Maslow's hierarchy of needs [11].

The present-day definitions of CSR emphasize cooperation with stakeholders. CSR is defined as the responsible management of business relations with all stakeholders, both internal and external ones. The stakeholder theory forms the core of today's concept of social responsibility [8].

In discussing corporate social responsibility, the literature in the past seemed to pay far less attention to seaports than other economic sectors [12]. Even today, the interest in CSR - though increased - is still fragmentary. The main thrust of scholarly debate is on ecology, port operations [13-15], shipping [16-18] and hinterland transport [19-21] as having an impact on the natural environment. However, publications on the social and economic responsibility of seaports are far fewer in number [22]. Fewer still are publications synthesizing various aspects of social responsibility in business [23, 24]. Publications describing the actual extent to which CSR has been implemented in seaports are a rarity [25-28].

According to ESPO, 45\% of European port management bodies out of a sample of 116 have been identified as having in place a formal CSR policy. In this respect, the pride of place goes to France, Italy and Spain where the figure stands at 60\% [28]. Similar figures are quoted for reporting socially responsible activities. Out of 186 major European seaports only 64 have posted no CSR information on their websites, while ports in Spain and Portugal are in the lead in terms of communicating their activities [26]. Ports which take a comprehensive approach to social responsibility are relatively few. Out of 37 Baltic Sea ports, only those at Gdańsk, Copenhagen-Malmo, Roenne, Stockholm and Vetspils are known to have implemented and publicized a comprehensive CSR policy [24]. In the other Baltic Sea ports the principal areas of social responsibility include the natural environment, port safety, business practices, and customer and employee relations [27].

In a 2013 study on social responsibility of the Port of Gdynia, K. Gromadowski [29] evaluated the activities of ZMPG-a SA, finding that the company had no CSR declaration or action plan, but certain areas of CSR were accounted for in the Rules of Organization laying down the tasks of individual company departments and general rights and obligations of employees. CSR was also included in the then-executed strategy which promised on-going action to ensure port stability and sustainable growth (mainly by supporting good practices and concern for society) [30]. ZMPG-a SA did not publicly report any data on socially responsible activities. The same author recommended a strategic approach to CSR in ZMPG-a SA and involving the employees by encouraging pro-social attitudes and voluntary work. When the Port of Gdynia was benchmarked against the port of Rotterdam, it became clear that CSR can be treated as a way of seeking innovative solutions to improve the relations of ports with their 
surroundings and better integrate their employees, for whom CSR may be a source of nonmonetary job satisfaction [29].

The actions taken to that end by ZMPG-a SA earned approval from J. Zurek who stressed ZMPG-a SA's transparent relations with stakeholder groups and its drive for stakeholder satisfaction [31]. The author emphasized that the company's successful record stemmed from its management's correct understanding of the CSR idea and its excellent relationship with the municipal and state authorities.

\section{Research method}

The paper adopts the case-study method to survey the Port of Gdynia. On that basis, an extensive analysis was made of actions taken by the body managing the port's infrastructure and premises and those taken by the enterprises operating inside the port and thereby contributing to its product offer. Secondary sources were used at the data-collection stage, such as scientific publications, papers and website content of ZMPG-a SA and commercial entities operating in the Port of Gdynia. The analysis of the data drawn from these sources allowed identifying the areas and extent of socially responsible actions seen in the Port of Gdynia.

The main research questions are:

- $\quad$ is ZMPG-a SA, as an infrastructure and port areas administrator, socially responsible?

- $\quad$ are the largest operators in the Port of Gdynia, which shape its services offer, socially responsible?

- what are the main areas of social responsibility of ZMPG-a SA and companies operating in the Port of Gdynia?

- are there any trends in the development of CSR in the Port of Gdynia?

The main hypothesis is that at present the Port of Gdynia is a socially responsible seaport. To verify this hypothesis, additional hypotheses were formulated: both ZMPG-a SA, as the entity managing infrastructure and port areas, and the largest enterprises operating in the Port of Gdynia are socially responsible; ZMPG-a SA and operating companies in the Port of Gdynia undertake activities in the most important areas of CSR; despite the lack of reports from previous years, the development of CSR in the Port of Gdynia is visible.

\section{Results}

In 2018, ZMPG-a SA published for the first time a report documenting its activities related to social responsibility (covering the years 2014-2016) [32]. The report is seen as an organizing effort to put in order the actions taken with respect to the company's stakeholders and the port as a whole. The report declares the company management board's wish to realize the idea of sustainable growth and acknowledge that social responsibility is an integral part of the company and that it is being executed in three basic areas: responsible business practices, environmental responsibility, good relations with the local community and a friendly work environment [32]. The report details the most important actions in the above-mentioned areas.

Responsible business practices were exemplified by [32]:

- $\quad$ action to improve the quality of services offered by the entire port. ZMPG-a SA can execute this action by investing in the port infrastructure, such as building, converting and modernizing the embankments as wells through facility and network renovation necessary for the port operators to do business,

- awareness-raising with respect safety on the premises by cooperating with business partners through education about health and safety on the premises and in facilities under ZMPG-a SA's management; providing instructions about procedure in case of 
emergency, fire safety rules in specific facilities and areas in ZMPG-a SA's charge and financing the Port Fire Brigade,

- concern for country-wide and regional growth by working together with state and local authorities for marine economy development; membership in national and international industry organizations; cooperating with the local authorities on projects related to the development of Gdynia, resolving conflicts at the interface of city and port, improving port accessibility and making the city a more attractive tourist destination.

ZMPG-a SA's responsibility for the natural environment is reflected in the following activities [32]:

- analysis of the impact of the operation of the port as a whole on the water, soil, air and biodiversity. The impact related to dust, noise and odour is the most serious nuisance to the communities in the port's immediate vicinity,

- $\quad$ on-going monitoring of the state of the environment on the port's premises including basin, rain and underground waters, sediments, water drinkability, soil purity and noise levels. The port management posts environmental and waste disposal information on its website for all those interested to read,

- efforts to limit electric power, heat and water consumption,

- action to maintain biodiversity due to closeness to the "Natura 2000" conservation areas, by recording fauna and flora, transferring animals and plants out of the areas intended for development,

- combating environmental hazards; planning for action against environmental hazards and water pollution at the port by around-the-clock protection against oil spills and other water-polluting agents,

- improving employee qualifications in the environmental protection department through numerous training courses and cooperation with research centres on research projects and propagating awareness of environmental protection issues related to marine transport.

ZMPG-a SA takes a pro-active approach to building good relations with the local community, in line with the "open port" model. This is exemplified by letting out outdoor port areas for artistic events, opening the company's concert hall to musical performances and other cultural events, leasing port facilities to the Emigration Museum in Gdynia, maintenance and development of generally available road infrastructure in the areas administered by the company, efforts to attract visits from passenger ships.

The company engages in on-going dialogue with the local community through meetings and consultations with Gdynia's municipal authorities, community consultation on upcoming investments, on-going data updates on the website and in the social media, cooperating with the local and national media, annual conferences to present the achievements and pans of the company for the entire port.

ZMPG-a SA also takes action for the local community by offering financial support to various projects and organizations, especially those whose activities involve children and teenagers, science, culture and sports. Over 1 million zlotys was allocated to charity purposes in 2014-2016. The company supports persons with disabilities, charity concerts and a hospice. The company also works together with schools and universities on research projects, conferences, publications, education and job training [32].

The company's management board takes action to provide a worker-friendly environment by building good and long-term relations. Out of a workforce of 300, 80 have been with the company for over 30 years, with the average time of employment being 20 years. Over 90 per cent of employees have a contract of full-time employment. The report stresses the importance of setting up clear principles of management of employee relations. These goals are served by the company statute, various sets of rules and other internal documents. No cases of lawbreaking have been reported in recent years. There are three trade unions operating at the 
company. Good employee relations are built through communication over an internal IT network, meeting of the workforce and the management. The company also takes health and safety compliance very seriously [32].

The company sees its employees as a special group of stakeholders and therefore invests heavily in their development by financing qualification-improving education (training courses, college degrees, conferences, English lessons, etc.). The employees are also offered financial aid to improve their living standards. Employee social benefit funds finance rest, recreation, holidays, trips, events, loans and other benefits, such as medical insurance, for employees and their children [32].

As a final word, it can be stated that the discussed document organizes the information on the activities of the management body of the Port of Gdynia's infrastructure and premises, and its publication on the website allows access to this information for all interested parties. This is also a way of publicizing ZMPG-a SA's social responsibility policy adopted by the company management board's resolution 156/VII/2017 and examples of CSR practices executed on behalf of its stakeholders. It should be added that prior to publishing the report, training was provided for all the company employees on the nature, aims and areas of CSR, as well as the actions taken in that respect by seaports (including Baltic Sea ports).

In the Port of Gdynia, an attitude of social responsibility is represented also by the commercial enterprises, as shown by a survey in July 2018 carried out among cargo terminal operators. These operators are ISO-certified for quality management, environmental and food safety systems compliance, and some of them implement GMP+ B3-compliant solutions for handling fodder and grain, have been certified for compliance with the International Ship and Port Facility Security Code, while their already implemented solutions are certified for compliance with other international standards. They are committed to quality improvement, concern for customer needs, investment in employee training, and responsible trading for environmental protection (or minimizing harmful impact on the natural environment). In this way, it is possible to identify the most important areas of CSR, in which commercial enterprises at the Port of Gdynia operate and - most importantly - inform of their activities on the Internet. Table 1 contains detailed results of the survey.

Table 1. Aspects of social responsibility of cargo terminal operators at the Port of Gdynia.

\begin{tabular}{|c|c|}
\hline Operator's name & $\begin{array}{c}\text { The most important actions and declarations } \\
\text { related to CSR }\end{array}$ \\
\hline Bałtycka Baza Masowa Sp. z o.o. & $\begin{array}{l}\text { - implemented ISO } 9001^{1} \\
\text { - confirmed compliance with ISPS } \\
\text { - environmentally friendly processes } \\
\text { - comfortable and customer-friendly ship spaces } \\
\text { - BBM quality management system policy (with } \\
\text { declarations of customer care, service quality } \\
\text { improvement, minimization of negative impact on the } \\
\text { environment, assurance of employee development, } \\
\text { training and job satisfaction) } \\
\text { - Czas Gdyni Best Investment Award in } 1999\end{array}$ \\
\hline OT Port Gdynia Sp. z o.o. & $\begin{array}{l}\text { - implemented ISO 9001, ISO } 22000^{3}, \text { GMP+B3 }{ }^{4} \\
\text { - OT Port Gdynia's rules of cooperation with contractors }\end{array}$ \\
\hline $\begin{array}{l}\text { Bałtycki Terminal Kontenerowy } \\
\text { Sp. z.o.o. }\end{array}$ & $\begin{array}{l}\text { - implemented ISO } 9001 \text {, ISO } 14001^{5} \text {, ISO } 22000 \\
\text { - ICTSI }{ }^{6} \text { business ethic code (declaration of beliefs, values } \\
\text { and commitment) relating to employee relations, fair and } \\
\text { ethical business practices, accounting accuracy, } \\
\text { compliance with local regulations } \\
\text { - confirmation of port facility compliance with ISPS }\end{array}$ \\
\hline
\end{tabular}




\begin{tabular}{|c|c|}
\hline Operator's name & $\begin{array}{c}\text { The most important actions and declarations } \\
\text { related to CSR }\end{array}$ \\
\hline $\begin{array}{l}\text { Bałtycki Terminal Zbożowy Sp. } \\
\text { z o.o. }\end{array}$ & $\begin{array}{l}\text { - implemented ISO } 22000, \text { GMP+B3 } \\
\text { - confirmation of port facility compliance with ISPS }\end{array}$ \\
\hline $\begin{array}{l}\text { Morski Terminal Masowy Gdynia } \\
\text { Sp. z o.o. }\end{array}$ & $\begin{array}{l}\text { - implemented ISO 9001, ISO 22000, GMP+B3, OHSAS } \\
\text { - company management board's announcement on coal } \\
\text { dust formed during cargo handling } \\
\text { - sponsoring, for example, Gdańsk Grain Exchange } \\
\text { - Gazela Biznesu Award in } 2013 \\
\text { - Forbes } 2017 \text { Diamond (for businesses which have noted } \\
\text { the highest increase in market value in the last three years) }\end{array}$ \\
\hline Gdynia Container Terminal SA & $\begin{array}{l}\text { - confirmation of port facility compliance with ISPS } \\
\text { - confirmation of service quality and efficiency } \\
\text { improvement } \\
\text { - declaration of investment in employee development } \\
\text { - declaration of environmentally friendly trading }\end{array}$ \\
\hline $\begin{array}{l}\text { KOOLE TANKSTORAGE } \\
\text { GDYNIA Sp. z o.o. }\end{array}$ & $\begin{array}{l}\text { - implemented ISO 9001, ISO 22000, GMP+B3 } \\
\text { - ISCC } \\
\text { - ISM Code } \\
\text { - EBIS } \\
\text { - declaration of concern for customer needs } \\
\text { - declaration of responsibility, reliability and credibility } \\
\text { - note of corporate culture focused on employee welfare } \\
\text { (people as the most important part of the organization) } \\
\text { - declaration of HSEQ }\end{array}$ \\
\hline Terminal ONICO GAS & $\begin{array}{l}\text { - information on potential hazards } \\
\text { - emergency prevention programme } \\
\text { - safety report } \\
\text { - declaration of "listening to the customers" } \\
\text { - declaration of superior quality of service (customers first) } \\
\text { - a high position on Forbes } 2018 \text { Diamonds list } \\
\text { - nominated for Sports Business Awards for Sport Sponsor } \\
\text { - sponsoring sports events and teams }\end{array}$ \\
\hline Aalborg Portland Polska Sp. z o.o. & $\begin{array}{l}\text { - implemented ISO 9001, ISO } \\
\text { - } 14001 \text {, OHSAS } \\
\text { - declaration of sustainable production, reduction of Nox, } \\
\mathrm{CO}_{2}, \mathrm{SO}_{2} \text { emissions, use of alternative energy sources, } \\
\text { environmental responsibility, energy economy, focus on } \\
\text { health and safety, creating value for society } \\
\text { - sustainable growth reports } \\
\text { - GRI reports } \\
\text { - certified for ISO } 50001^{12} \\
\text { - } \text { EMAS }^{13}\end{array}$ \\
\hline SPEED Sp. z o.o. & $\begin{array}{l}\text { - ISO } 22000 \\
\text { - certified for SGCSH-COC }{ }^{14}\end{array}$ \\
\hline
\end{tabular}

${ }^{1}$ ISO 9001 is a standard relating to quality management systems.

${ }^{2}$ ISPS (International Ship and Port Facility Security Code).

${ }^{3}$ ISO 22000 is a standard relating to food safety systems.

${ }^{4} \mathrm{GMP}$ Plus is a fodder safety standard for manufacturers of products audited in the fodder chain. GMP+ B3 is applicable to entities collecting grain, trading in grain and fodder, storing or distributing grain.

${ }^{5}$ ISO 14001 is a standard relating to environmental management systems.

${ }^{6}$ ICTSI (International Container Terminal Services, Inc.) is the owner of BCT.

${ }^{7}$ OHSAS is a standard related to work safety management systems. 
${ }^{8}$ ISCC (International Sustainability \& Carbon Certifiction) is a certification system for the production chain of biomass and biofuels, allowing for identification of energy carriers provided in a sustainable manner and with the use of renewable sources.

${ }^{9}$ ISM Code (International Safety Management Code) sets out an international standard relating to safe management and operation of ships and prevention of pollution.

${ }^{10}$ EBIS European Barge Inspection Scheme.

${ }^{11}$ HSEQ Health, Safety, Environment \& Quality.

${ }^{12}$ ISO 50001 is a standard relating to energy management.

${ }^{13}$ EMAS (Eco-Management and Audit Scheme) is a system of environmental management.

${ }^{14} \mathrm{COC}$ (chain of custody) is a standard relating to forestry articles.

Source: The author's own work [33-42]

The data in Table 1. demonstrates that port operators are active in the following areas of CSR: good business practices and responsibility to business partners (ISO 9001 certificates, declaration of fair and ethical business practices), natural environment protection (ISO 14001, EMAS, COC, ISO 50001, declarations of emissions reduction, and energy and water economy), safety at port, safety of cargo handling (ISO 22000, GMP+B3, confirmation of port facility compliance with ISPS, OHSAS), concern for customer satisfaction, high quality of services, flexibility in tailoring services to customer needs (declarations), social responsibility to the urban and regional population (informing of hazards related to cargo handling, safety reports, emergency prevention programme, sponsoring cultural and sporting events, sponsoring sports teams), good employee relations (declaration of concern for employee development, improvement and job satisfaction, information of corporate culture and value of human capital as a resource). Implementation of quality of management systems standards in the surveyed enterprises (ISO and other certificates) as well as undertaking activities in new areas testify to the CSR development of operating enterprises in the Port of Gdynia.

It should be added that similar declarations were posted on the Internet by commercial enterprises operating on the port's premises (freight forwarders, shipowners, property valuers and controllers, land carriers and other businesses).

\section{Conclusions}

The analysis of the collected data allowed identifying the most important areas of activity taken up as part of corporate social responsibility for seaports. This emphatically applies to the entity governing the port's infrastructure and premises as well as commercial companies providing services for cargo, passengers and ships.

It was not until 2018 that ZMPG-a SA published the first documentary evidence of CSRrelated action. This does not mean that social responsibility was not a concern beforehand. Different kinds of activities related to responsible business practices, environmental responsibility, good relations with the local community and employees, but no relevant periodic reports were produced before. The company did not have a formal CSR policy even though certain issues related to social responsibility were raised in the development strategy in the years 2004-2015 [30]. It seems that the document entitled Social Responsibility of ZMPG-a SA. Policy and Good Practices in 2014-2016 not only reports socially responsible action but also publicizes the company's CSR policy correlated with The's Development Strategy till 2027 and forestalls further consistent action in that area. Therefore, it should be expected that more reports, modelled preferably on GRI - Global Reporting Initiatives, will be produced.

The analysis of data relating to socially responsible activities of commercial enterprises operating at the Port of Gdynia suggests that these are also engaged in efforts that can be classified into various CSR areas. These include in particular good business practices and responsibility to business partners, environmental protection, port and cargo safety, concern for customer satisfaction, high quality of services, responsibility to society and good employee 
relations. This is borne out by numerous compliance certificates issued by ISO and other organizations as well as declarations and awards. Of course, the individual entities differ in the extent to which they pursue CSR activities. However, it is true that where the management body and other enterprises providing port services in Gdynia engage in various forms of activity in the most important areas of CSR, they can be considered socially responsible. Therefore, the Port of Gdynia can be considered socially responsible. However, it is advisable to expect the adoption of a uniform CSR strategy in all the key areas by the Port of Gdynia as a whole.

\section{References}

1. Regulation (EU) no 1316/2013 of the European Parliament and of the Council of 11 December 2013 establishing the Connecting Europe Facility

2. www.port.gdynia.pl

3. Ustawa z dnia 20 grudnia 1996 roku o portach i przystaniach morskich, Dz. U. 1997, nr 9

4. A. Crane, A. McWilliams, J. Moon, D.S. Siegiel (ed.), The Oxford Handbook of Corporate Social Responsibility (Oxford University Press, New York, 2008)

5. W.B. Werther, D. Chandler, Strategic Corporate Social Responsibility: Stakeholders in a Global Environment (Sage Publications, 2011)

6. J. Kronenberg, T. Bergier (ed.), Wyzwania zrównoważonego rozwoju $w$ Polsce (Fundacja Sendzimira, Kraków, 2010)

7. J. Nakonieczna, Społeczna odpowiedzialność przedsiębiorstw międzynarodowych (Difin, Warszawa, 2008)

8. U. Gołaszewska-Kaczan, Zaangażowanie społeczne przedsiębiorstwa (Wydawnictwo Uniwersytetu w Białymstoku, Białystok, 2009)

9. H. Bowen, Social Responsibilities of the Businessman (Harper, New York,1953)

10. A.B. Carroll, Academy of Management Review, 4, 497-505 (1979)

11. A.B. Carroll, Business Horizons, 34, 4 (1991)

12. T. Vanelslander, Social Resposibility Journal, 12, 2 (2016)

13. R.M. Darbra, N.Pittam, K.A. Royston, J.D. Darbra, H. Journee, Journal of Environmental Management 90, 3 (2009)

14. C. F.Wooldridge, C. McMullen, V. Howe, Marine Policy, 23, 4 (1999)

15. ESPO, Green Guide: Towards excellence in port environmental management and sustainability (Brussels, ESPO, 2012)

16. N.A. Braathen (ed.), Environmental impacts of international shipping: The role of ports, (OECD Publishing, 2011)

17. J.Berechman, P. Tseng, Transportation Research Part D, 17, 1 (2012)

18. D-W. Song, Ph.M. Panayides, Maritime Logistics: Contemporary Issues, (2012)

19. V. Roso, Transportation Research Part D, 12, 7 (2007)

20. C-H. Liao, P-H. Tseng, K. Cullinane, C-S. Lu, Energy Policy, 38, 9 (2010)

21. R. Bergqvist, N. Egels-Zanden, Research in Transportation Business \& Management 5 (2012)

22. G. Denktas Sakar, C. Karatas Cetin, The Asian Journal of Shipping and Logistics, 28, 3 (2012)

23. H. Haralambides, G. Gujar, Maritime Economics and Logistics, 14, 1 (2013)

24. J. Lam, Y. Gu, International Journal of Shipping and Transport Logistics, 5, 3 (2013)

25. C. Karatas Cetin, G. Denktas Sakar, Journal of Graduate School of Social Sciences, 12, $29(2015)$

26. S. Santos, L.L. Rodrigues, M.C. Branco, Journal of Cleaner Production, 112, 2935-2942 (2016) 
27. R. Płoska, J. Próchniak, Zarządzanie i Finanse Journal of Management and Finance, 15, 2 (2017)

28. P. Verhoeven, European port governance, report of an inquiry into the current governance of European seaports (The ESPO Fact Finding Report, Brussels, 2011)

29. K. Gromadowski, Problemy integracji działań CSR z ogólna strategia Portu Gdynia na podstawie benchmarkingu z portem Rotterdam (PRET SA, Warszawa 2013)

30. Zarząd Morskiego Portu Gdynia SA, Strategia rozwoju Portu Gdynia do 2015 roku (Gdynia 2003)

31. H. Klimek (ed.) Porty morskie $w$ perspektywie przestrzennej, ekonomicznej, transportowej, logistycznej i społecznej (Wydawnictwo Uniwersytetu Gdańskiego, Gdańsk, 2016)

32. Zarząd Morskiego Portu Gdynia SA, Społeczna odpowiedzialność Zarządu Morskiego Portu Gdynia SA. Polityka i dobre praktyki w latach 2014-2016 (ZMPG-a SA, Gdynia, 2018)

33. www.gct.pl

34. www.bbm.gdynia.pl

35. www.otport.gdynia.pl

36. www.bct.gdynia.pl

37. www.btz.gdynia.pl

38. www.mtmg.gdynia.pl

39. www.koole.com

40. www.onico-gas.pl

41. www.aalborgportland.pl

42. www.speed.gdynia.pl 